The American Journal of Political Science Law and Criminology

(ISSN - 2693-0803)

VOLUME 04 ISSUE 01 Pages: 80-85

SJIF IMPACT FACTOR (2020: 5. 453) (2021: 5. 952)

OCLC - 1176274523 METADATA IF - 7.659

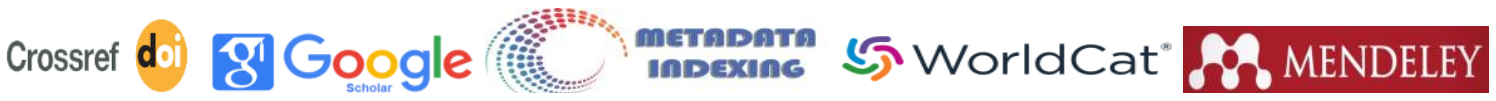

Research Article

\title{
FEATURES OF THE LABOR LAW OF THE EUROPEAN UNION
}

\author{
Submission Date: January 09, 2022, Accepted Date: January 20, 2022, \\ Published Date: January 30, 2022 \\ Crossref doi: https://doi.org/10.37547/tajpslc/Volume04Issue01-13
}

Journal Website: https://theamericanjou rnals.com/index.php/ta jpslc

Copyright: Original content from this work may be used under the terms of the creative commons attributes 4.0 licence.

Makhamatov Mahmud Makhamataminovich

Acting Assistant Professor of the Department of International Law and Human Rights, Tashkent State Law University, Doctor of Philosophy (PhD) in Law, Uzbekistan

\section{ABSTRACT}

The article examines the interaction of the national labor legislation of the member states of the European Union with European labor law, the influence of the Labor law of the European Union on the national legislation of the member states, the features of the labor legislation of the European Union, which differ from the legislation of other countries, a comparative analysis of the labor legislation of the Republic of Uzbekistan.

\section{KEYWORDS}

Labor standards, national labor law, labor legislation, supranational labor law, working conditions.

\section{INTRODUCTION}

Today, in the European Union, with an area of 4381376 square kilometers, live more than 500 million people, representing more than 100 nationalities, speaking 46 languages. Geographically, 15 of the member states are from Western Europe and 11 from Central and Eastern Europe. Two (Malta, Cyprus) are located in the Mediterranean basin.
Member States of the European Union vary according to their form of government, regional government structure, an administrative form of government and level of economic development. The legal nature of the European Union and its integration processes is complex. The multifaceted «parallel lines» between the national legal systems and international law, national 
The American Journal of Political Science Law and Criminology (ISSN - 2693-0803)

VOLUME 04 ISSUE 01 Pages: 80-85

SJIF IMPACT FACTOR (2020: 5. 453) (2021: 5. 952)

OCLC - 1176274523 METADATA IF - 7.659

law and European Union Law, European Union Law and international law are a completely new reality in the modern system of international legal relations. Methods of implementing European Union law into national legal systems are the most delicate aspect of the integration process $[13,-$ P. 7.].

More than 240 million people are employed in the European Union, therefore, the impact of European labor legislation is huge. Therefore, a small number of works have been done in our country on this issue, and the intensification of cooperation between the Republic of Uzbekistan and European Union member states, the employment of citizens of our country in European countries creates a need for a comprehensive study of labor legislation.

European labor law as the labor law of the Republic of Uzbekistan complies with all the basic principles and rules of international labor law. As of December 1, 2021, the Republic of Uzbekistan has ratified 18 conventions of the International Labor Organization (hereinafter ILO). There is a difference in the status of ratification of ILO conventions by European Union member states: Spain (133), France (128), Italy (114), Denmark, the Czech Republic, Greece, and Hungary (73 each), other countries have ratified relatively little, for example, Estonia [5]. The Republic of Uzbekistan and each of the European Union member states have ratified all 8 conventions of the ILO which is recognized as fundamental [6].

The national legislation of the Republic of Uzbekistan and the member states of the European Union is based on international labor standards. In addition, the legal systems of Uzbekistan and the member states of the European Union are basically the same - they belong to the Roman-German legal family, and we can see their similarities in several ways. In particular: the first: by sources of law (the main source of law is a normative legal document);

the second: by codification (European Union member states have labor codes in a number of countries, also it should be noted that most of the similarities here are due to Eastern European countries, whereas, in many Western European countries, labor relations are governed by civil codes).

One of the peculiarities of the labor legislation of the Republic of Uzbekistan is that it is valid in the territory of our state, in other words, it has a national character. European labor law is superior to national law and is binding on all member states. The jurisdiction of the European Union is limited to the jurisdiction of the member states and applies the principles of proportionality and subsidiarity. The European Union can only act within the territory agreed by its member states. Labor rights are formed independently at the national level within the state, and the European Union complements national legislation.

According to researcher I.A Filipova, European labor law was originally developed as one of the tools to create a common market that will help to gradually integrate into economic integration and political context. Later, the European social model began to develop through the harmonization of national legislation [11, - P. 203]. According to the approach of M. Schmid approach, "the harmonization process is carried out at the European Union level through the use of flexible methods aimed at strengthening basic social rights, as well as the convergence of national laws [7, - P. 12].

European labor law includes documents of the European Union (mainly on socio-economic issues) and documents of the Council of Europe (on human rights). 
The American Journal of Political Science Law and Criminology

(ISSN - 2693-0803)

VOLUME 04 ISSUE 01 Pages: 80-85

SJIF IMPACT FACTOR (2020: 5. 453) (2021: 5. 952)

OCLC - 1176274523 METADATA IF - 7.659

The documents of the European Union may also contain references to Council of Europe documents [1].

In addition to the European Social Charter (1996) and regional international treaties, European Union legislation and norms of judicial practice are also a source of European labor law. European legislation includes rules, regulations and directives adopted by the Council of the European Union and the European Parliament according to the proposal of the European Commission. These documents are adopted based on the memorandum of associations and are therefore called "acquired rights" [13, - P. 402]. Decisions and regulations are directly applicable, and directives are enforced by national law. The directive obliges the country to take measures to achieve the goals set out in the social partnership documents for a certain period of time (usually 3 years). The directive is a document that has its characteristics in the system of European Union legislation. It mainly can be targeted at all member states, and only occasionally at one or more member states. Furthermore, it is not enough to provide the text of the directive in the law, all the necessary legal measures must be taken to achieve the goal set in the directive.

The documents of the European Union take precedence over national law. If the state does not bring its national legislation in line with the directive, the case can be challenged in the court of the European Union. In some cases, countries require national court judges to directly ask the European Court of Luxembourg to interpret European law.

The above-mentioned issues were related to some features of the European Union norm-setting documents. These documents are also specific to the legal regulation of key issues in the field of labor, including labor protection, employment contracts, working hours, rest time, salaries, protection of personal data of employees and social partnership, we will consider these aspects below.

European labor law regulates primarily regulates issues related to employee health and occupational safety. The Council of the European Union adopts guidelines, the basic norms of European labor law - the minimum requirements. They must be followed by all member states of the European Union. The purpose of these standards is to ensure progress in improving working conditions and occupational safety. As mentioned above, European standards complement the national legislation of member states of the European Union.

Most of the norms of European labor law are set out in the directives. For example, the Council of the European Union Framework Directive 89/391 / EES of 12 June 1989 [2] sets minimum standards, according to it, if the level of protection of employees' health in certain member states of the European Union is high, it cannot be reduced. The directive envisages a risk-based approach in the field of occupational safety, which requires employers to take preventive measures, assess and eliminate risks, and prevent harm to the lives and health of employees. The directive envisages a risk-based approach in the field of occupational safety, which requires employers to take preventive measures, assess and eliminate risks, and prevent harm to the lives and health of employees. Directives of the Council of the European Union are often concerned with specific occupational safety issues.

In European labor law, there is no such thing as a "European employment contract". However, there is an employment contract itself, the contract is concluded for an indefinite period, as a general rule, also each member state must determine under what circumstances a fixed-term contract becomes an indefinite contract. This is stated in the Council of the European Union's Directive 1999/70/ CE of 28 June 
The American Journal of Political Science Law and Criminology (ISSN - 2693-0803)

VOLUME 04 ISSUE 01 Pages: 80-85

SJIF IMPACT FACTOR (2020: 5 - 453) (2021: 5. 952)

OCLC - 1176274523 METADATA IF - 7.659

1999, as well as in the Framework Agreement on Work for an indefinite period of 18 March 1999. In such case, the employer must notify the employee of the terms of the employment contract within 2 months after the start of work (Directive 91/533/EEC of 14 October 1991).

Directive 91/533/EEC contains the necessary terms of a written employment contract, letter of guarantee or other documents, which are as follows:

- Identify the parties;

- A place of work;

- Name (position), qualification, category or job title;

- Date of commencement of work activities;

- Annual vacation period;

- Notice period in case of termination of the contract;

- Components of wages and the frequency of its payment, in which currency it is paid;

- Daily and weekly working hours;

- Recall employee-related social partnership documents;

- Duration of business trips abroad (if any).

In several European countries, there is no general requirement for a notice period in the termination of an employment contract. In many cases, this is determined by the network agreement and other documents of the social partnership, and therefore it should be specified in the employment contract.

Another feature is that, unlike the labor legislation of the Republic of Uzbekistan (Labor Code of the Republic of Uzbekistan, Article 74) [4], under European law, there is no requirement that an employment contract is in writing.

According to European Union Regulation 593/2008 on the right to contractual obligations, if an employment contract is concluded between representatives of different states, it is governed by the legislation of the country chosen by the employer-employee agreement. The restriction in such a selection is that the imperative requirements of the state in which the employee is working (e.g. working time limit, minimum wage, etc.) must not be violated.

The absence of strict restrictions on the content of the employment contract allows the European Union member states to independently determine additional terms of the employment contract in accordance with the legislation of the member states. For instance, the law of France provides for the following:

- Movement status (allowing the employer to transfer the employee to another place of work, to another place);

- The condition of non-competition (absence of the right to be employed by competing companies after the dismissal of the employee);

- The right to inviolability (which was introduced in 2017 to ensure the inviolability of the employee's vacation time) and others.

"Traditional employment is full-time employment based on an employment contract with a particular employer" [14. - P. 118]. Here working hours play a key role. From the point of view of European labor law, working time is the entire period during which an employee is at the disposal of the employer in the workplace, in the performance of his work or duties (Directive 2003/88/EC of the European Parliament and the Council of the European Union of November 4, 2003 "On Some Aspects of the Organization of Working Hours"). According to I.A Filipova, such a "broad" definition of working hours in European labor law does not directly link working hours to wages, but only affects the health of employees. [11, - P. 205]. 
The American Journal of Political Science Law and Criminology (ISSN - 2693-0803)

VOLUME 04 ISSUE 01 Pages: 80-85

SJIF IMPACT FACTOR (2020: 5. 453) (2021: 5. 952)

OCLC - 1176274523 METADATA IF - 7.659

Indeed, if we focus on the practice of the European Union court, non-compliance with the requirements of Directive 2003/88 / ES in the legislation of Spain, Germany, France, the Czech Republic and other countries, in particular, working time is considered only in cases where the time worked is calculated [3].

According to Directive 2003/88 / EC, each Member State of the European Union is required to provide workers with annual paid leave of at least 4 weeks. According to Article 134 of the current Labor Code of the Republic of Uzbekistan, the annual basic leave should not be less than 15 working days [4]. We can see that this period is slightly different from the international and European standards. At the same time, "It is clear from our current labor legislation that a five-day working week on Saturdays is defined as the addition of annual leave to employees, even though it is a traditional holiday. In other words, Convention №52 on Paid Annual Leave stipulates more preferential rules for employees in calculating the duration of annual leave than in labor laws or other regulations. This means that in accordance with our labor law, the provisions of the convention must be applied in such relations. That is, Saturdays are not included in the annual leave for employees working in a five-day working week" [10, P. 104-105].

In addition to Directive 2003/88/EC, the European Court of Justice of 20 January 2009 ruled that paid leave cannot be replaced by paid compensation. The period of incapacity for work is not included in this. Termination of the employment contract will allow replacing the paid leave, which is unpaid yet, with paid compensation.

Lawyer M. Lovich notes that "European labor law is aimed at developing social partnership. Increasing the role of social partners will allow many issues to be resolved without changing the legislation and increasing the effectiveness of regulation, because the social partners themselves agree on all the conditions in advance" [8, - P. 103].

The European Confederation of Trade Unions and the largest employers' associations have reached a number of inter-professional agreements, including on long-distance work, anti-stress, anti-violence at work, and others. It should also be noted that once the agreement has been reached, the social partners will direct their agreement to the agreement at the national level without issuing a directive. It should also be noted that once the agreement has been reached, the social partners will direct their agreement to the agreement at the national level without issuing a directive. There are also European sectoral agreements in the postal, agricultural and other fields, which must comply with the requirements of previously adopted directives. At the same time, the European Court of Justice has the right to review its compliance with European law.

According to researcher Ye.N.Egorova: "One of the specific aspects of European labor law is that its subject matter includes the regulation of the freedom of movement of civilian workers within the European Union for employment. The European Union labor law regulates the formation and operation of a single integrated labor market" [9. - P. 12].

One of the features of European labor law is that in European labor law jurisprudence is recognized as a source of law, as is the national legislation of the Member States of the European Union. The decisions of the European Court have been recognized as taking precedence over national legislation and decisions of national courts can significantly supplement existing legislation. For example, in France, a court case has created a new basis for the termination of an employment contract not provided for in the French 
The American Journal of Political Science Law and Criminology (ISSN - 2693-0803)

VOLUME 04 ISSUE 01 Pages: 80-85

SJIF IMPACT FACTOR (2020: 5. 453) (2021: 5. 952)

OCLC - 1176274523 METADATA IF - 7.659
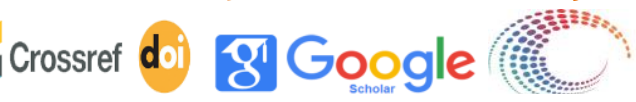

metapดTa InDExIne 5. WorldCat fô MENDELEY

Publisher: The USA Journals

Labor Code: termination of an employment contract by an employee through the fault of the employer and termination of an employment contract by a court [ 12 . - P. 41].

As we can see, despite the existing differences in the national labor legislation of the European Union member states, there is a tendency to harmonize the norms of national legislation through the general norms of European labor law, which in turn allows for more successful development in the common territory of the European Union.

\section{REFERENCES}

1. Directive (EU) $2018 / 957$ of the European Parliament and of the Council of 28 June 2018 amending Directive $96 / 71 / \mathrm{EC}$ concerning the posting of workers in the framework of the provision of services. PE/18/2018/REV/1 https://eurlex.europa.eu/legal-

content/EN/TXT/?uri=CELEX\%3A32018L0957

2. Directive $89 / 391 / \mathrm{EEC}$ on the introduction of measures to improve the safety and health of workers at work. http://online.budstandart.com/ru/catalog/docpage?id_doc $=47940$

3. Request for a preliminary ruling pursuant to Article 98(1) of the Rules of Procedure of the Court of Justice/ Case C-477/21 https://curia.europa.eu/juris/showPdf.jsf?text=wo rk\%2Bhour\&docid $=247290$ \&pagelndex $=0 \&$ doclan $\mathrm{g}=\mathrm{EN} \&$ mode $=$ req $\& \mathrm{dir}=\&$ occ $=$ first $\&$ part $=1 \& \mathrm{cid}=58$ 7062

4. Labor Code of the Republic of Uzbekistan https://lex.uz/docs/142859

5. Ratifications by country https://www.ilo.org/dyn/normlex/en/f?p=1000: 11001:::NO::: (05.12.2021й.)
6. Ratifications
for
Uzbekistan
https://www.ilo.org/dyn/normlex/en/f?p=
1000:11200:0::NO:11200:P11200
_COUNTRY_ID:103538 (05.12.2021й.)

7. Schmitt M. Droit du travail de l'Union européenne. Bruxelles: Larcier, 2012. - P. 12.

8. Löwisch M. Labor Law in Europe // Ritsumeikan Law Review. 2003. №20. - C. 103.

9. Egorova E.N. Basics of European Union labor law. Dissertation abstract. For a degree in legal sciences in the specialty 12.00 .10 - International law; European law. - M., 2013. - P. 12.

10. Makhamatov M.M. Implementation of international standards on working hours and paid holidays into national legislation// Yurist axborotnomasi - Вестник юриста - Lawyer herald. № 3 (2021). - P. 104-105.

11. Filipova I.A. Labor law of the European Union: common features and differences in comparison with Russian labor law.//Bulletin of the Nizhny Novgorod Academy of the Ministry of Internal Affairs of Russia, 2018, № 1 (41). - P. 203; 205.

12. Filipova I.A. The grounds and features of the termination of an employment contract under modern Russian and French labor legislation//State and Law. 2016. №3. - P. 41.

13. Yunusov Kh.M. European Union law: Textbook. 3rd edition. - Tashkent: University of World Economy and Diplomacy, 2019. - P. 7; 402.

14. Makhamatov $M$. Issues of improving labor legislation in the digital economy// Yuridik fanlar axborotnomasi- Вестник юридических наук Review of law sciences. №2 (2020). - B. 118. 